VIVIANI, Rodrigo Andrade. O direito penal como instrumento destinado à proteção do meio ambiente: análise no contexto da constituição federal brasileira. Revista Eletrônica Direito e Política, Programa de Pós-Graduação Stricto Sensu em Ciência Jurídica da UNIVALI, Itajaí, v.11, n.2, 2o quadrimestre de 2016. Disponível em: www.univali.br/direitoepolitica - ISSN 1980-7791.

\title{
O DIREITO PENAL COMO INSTRUMENTO DESTINADO À PROTEÇÃO DO MEIO AMBIENTE: ANÁlISE NO CONTEXTO DA CONSTITUIÇÃO FEDERAL BRASILEIRA
}

\author{
THE CRIMINAL LAW AS AN INSTRUMENT TO PROTECTION THE \\ ENVIRONMENT: ANALYSIS IN THE CONTEXT OF THE FEDERATIVE \\ BRAZILIAN CONSTITUITION
}

\section{Rodrigo Andrade Viviani ${ }^{1}$}

SUMÁRIO: Introdução. 1. Proteção constitucional do meio ambiente no ordenamento jurídico brasileiro. 2. O bem jurídico como objeto de proteção do Direito Penal. 3. Necessidade da intervenção penal em matéria ambiental. 4. O Direito Penal como instrumento destinado à proteção do meio ambiente: Análise no contexto do ordenamento jurídico brasileiro. Considerações finais. Referências das fontes citadas.

\section{RESUMO}

O presente artigo tem por objetivo expor a relevância e necessidade da intervenção do Direito Penal para proteger o meio ambiente no contexto do ordenamento jurídico brasileiro, especialmente levando em consideração os riscos desencadeados na sociedade contemporânea, provenientes do progresso tecnológico e industrial. Para tanto, utilizando-se o método indutivo, pretende-se abordar, inicialmente, a estrutura normativa constitucional a respeito do meio ambiente, inclusive apontando a sua natureza de direito fundamental. A partir disso, pretende-se discorrer sobre a importância da intervenção penal na esfera ambiental, que teria um caráter de prevenção, contribuindo, sobretudo, com a educação ambiental. Ao final, conclui-se que o Direito

\footnotetext{
1 Promotor de Justiça do Ministério Público de Santa Catarina. Mestrando em Ciência Jurídica na Universidade do Vale do Itajaí - UNIVALI, paralelamente ao curso Máster Universitario en Derecho Ambiental y de la Sostenibilidad (MADAS), da Universidade de Alicante (Espanha). Endereço eletrônico: rodrigoav82@yahoo.com.br.
} 
VIVIANI, Rodrigo Andrade. O direito penal como instrumento destinado à proteção do meio ambiente: análise no contexto da constituição federal brasileira. Revista Eletrônica Direito e Política, Programa de Pós-Graduação Stricto Sensu em Ciência Jurídica da UNIVALI, Itajaí, v.11, n.2, 2o quadrimestre de 2016. Disponível em: www.univali.br/direitoepolitica - ISSN 1980-7791.

Penal, em razão dos novos interesses inerentes à sociedade pósindustrial, mostra-se uma visa adequada e necessária para proteger o meio ambiente.

PALAVRAS-ChAVE: Meio ambiente; sociedade de risco; Direito Penal; Constituição; direito fundamental.

\section{ABSTRACT}

This article intends to explain the relevance and the necessity of the intervention of criminal law to protect the environment in the context of the brazilian legal system, especially taking into account the riskis triggered in contemporany society, from the technological and industrial progress. Therefore, using the inductive method, we intend to address, first, the constitutional regulatory framework regarding the environment, including pointing to its character as a fundamental right. From this, we intend to discuss the importance of criminal intervention in the environmental sphere, which would have a character of prevention, contributing mainly to environmental education. Finally, it is concluded that the criminal law, in reason of new interests inherent in post-industrial society, shown appropriate and necessary to protect the environment.

KEYWORDS: Environment; risk society; Criminal Law; Constitution; fundamental right.

\section{INTRODUÇÃO}

Em virtude do avanço tecnológico e industrial que impulsionou o crescimento econômico na sociedade contemporânea, sobrevieram, nas últimas décadas, alterações consideráveis sobre os elementos que integram a biosfera, que estariam a comprometer a biodiversidade e o próprio destino da humanidade.

Esse desequilíbrio ecológico, assim, seria proveniente da sociedade industrial contemporânea, marcada por riscos, que teriam a potencialidade de comprometer a vida e a saúde humana.

Por isso, após a Conferência de Estocolmo, realizada em 1972, o meio 
VIVIANI, Rodrigo Andrade. O direito penal como instrumento destinado à proteção do meio ambiente: análise no contexto da constituição federal brasileira. Revista Eletrônica Direito e Política, Programa de Pós-Graduação Stricto Sensu em Ciência Jurídica da UNIVALI, Itajaí, v.11, n.2, 2o quadrimestre de 2016. Disponível em: www.univali.br/direitoepolitica - ISSN 1980-7791.

ambiente passou a ser objeto de especial atenção pela comunidade internacional, fato este que pode ser observado na quantidade expressiva de tratados, convenções e legislações editadas nas últimas décadas.

Diversos Estados de Direito, nesse desiderato, têm albergado, em seus respectivos textos constitucionais, normas tendentes a proteger o meio ambiente, inclusive as erigindo ao patamar de direito fundamental (no caso, de terceira dimensão).

A Constituição da República Federativa do Brasil de 1988, seguindo essa tendência, proclamou, em seu texto, um arcabouço de normas visando resguardar o meio ambiente. No bojo do texto constitucional brasileiro, a propósito, estabeleceu-se um sistema tríplice de responsabilidade na seara ambiental, no sentido de que o causador de dano ambiental, seja ele pessoa física ou jurídica, pode ser submetido à responsabilização na esfera criminal, cível e administrativa.

O problema reluzido neste estudo, assim, consiste em averiguar se o meio ambiente, atualmente, encontra-se ameaçado em virtude do processo industrial contemporâneo, e se o Direito Penal, por outro lado, deveria ser acionado para a sua completa proteção. Para tanto, pretende-se analisar se os mecanismos dispostos no âmbito civil e administrativo seriam (ou não) suficientes para assegurar a plena proteção ecológica.

O presente trabalho, nesse sentido, levando em consideração os novos desafios da sociedade contemporânea, atrelados ao fenômeno da globalização, tem por objetivo examinar a relevância e a necessidade da 
VIVIANI, Rodrigo Andrade. O direito penal como instrumento destinado à proteção do meio ambiente: análise no contexto da constituição federal brasileira. Revista Eletrônica Direito e Política, Programa de Pós-Graduação Stricto Sensu em Ciência Jurídica da UNIVALI, Itajaí, v.11, n.2, 2o quadrimestre de 2016. Disponível em: www.univali.br/direitoepolitica - ISSN 1980-7791.

intervenção do Direito Penal para a proteção do bem jurídico ambiental, dando-se enfoque precípuo ao ordenamento jurídico brasileiro.

Para que se possa alcançar as conclusões quanto a tal objetivo, é examinada a seguinte hipótese: O Direito Penal, no ordenamento jurídico brasileiro, se revela uma via indispensável para a proteção do meio ambiente, levando em consideração a especial proteção que the foi conferida pela Constituição Federal de 1988.

Para tanto, pretende-se discorrer, inicialmente, sobre a concepção de meio ambiente, abordando a normativa jurídica que o permeia, inclusive examinando se a proteção constitucional ambiental estaria alçada ao patamar de norma fundamental.

Na sequência, partindo da premissa que o meio ambiente se trataria de um direito fundamental previsto expressamente na Constituição Federal de 1988, objetiva-se correlacioná-lo com a concepção de bem jurídico tutelado pelo Direito Penal, o qual, modernamente, só pode ser acionado em ultima ratio, ou seja, quando os demais ramos do Direito não forem suficientes para solver a contenda, na senda dos postulados da intervenção mínima, subsidiariedade e fragmentariedade.

Ao final, analisar-se-á a necessidade da intervenção penal na seara ambiental, com enfoque no ordenamento jurídico brasileiro. Essa relevância na intervenção penal, conforme se discorrerá no presente estudo, tem arrimo, principalmente, no caráter de prevenção do meio ambiente. 
VIVIANI, Rodrigo Andrade. O direito penal como instrumento destinado à proteção do meio ambiente: análise no contexto da constituição federal brasileira. Revista Eletrônica Direito e Política, Programa de Pós-Graduação Stricto Sensu em Ciência Jurídica da UNIVALI, Itajaí, v.11, n.2, 2o quadrimestre de 2016. Disponível em: www.univali.br/direitoepolitica - ISSN 1980-7791.

Quanto à metodologia, utilizou-se, neste estudo, o método indutivo ${ }^{2}$, mediante a técnica da categoria, $^{3}$ do conceito operacional ${ }^{4}$ e do referente ${ }^{5}$, além de pesquisa bibliográfica, doutrinária, jurisprudencial e legislativa pertinente ao assunto examinado.

\section{PROTEÇÃO CONSTITUCIONAL DO MEIO AMBIENTE NO ORDENAMENTO JURÍDICO BRASILEIRO}

O crescimento econômico que permeia a sociedade contemporânea, principado na Revolução Industrial do século XVIII, mas que atingiu o seu apogeu nas últimas décadas em razão do fenômeno da globalização, têm ensejado preocupação de ordem global, especialmente levando em consideração os reflexos negativos ocasionados ao meio ambiente.

Essa conjuntura proveniente do emprego de novas tecnologias e métodos científicos, que ganhou maior dimensão a partir da metade do século XX, veio a configurar o que Ulrich Beck denominou de "sociedade de risco". Os riscos de que fala Beck, inerentes à sociedade contemporânea, seriam diversos daqueles atinentes ao período que intermediou o século XIX até a metade do século XX, já que tratariam

2 O método indutivo, segundo de Cesar Luiz Pasold, consiste em "pesquisar e identificar as partes de um fenômeno e colecioná-la de modo a ter uma percepção ou conclusão geral". PASOLD, Cesar Luiz. Metodologia da pesquisa jurídica: teoria e prática. 12. ed. São Paulo: Conceito Editorial, 2011, p. 82.

3 Categoria, na definição de Pasold, significa "a palavra ou expressão estratégica à elaboração e/ou expressão de uma idéia". PASOLD, Cesar Luiz. Metodologia da pesquisa jurídica: teoria e prática, p. 25.

4 Conceito operacional, no dizer de Pasold, "é uma definição para uma palavra ou expressão, com o desejo de que tal definição seja aceita para os efeitos das idéias que expomos". PASOLD, Cesar Luiz. Metodologia da pesquisa jurídica: teoria e prática, p. 50 .

5 O referente, na conceituação de Pasold, "é a explicitação prévia do(s) motivo(s), do(s) objetivo(s) e do produtor desejado, delimitando o alcance temático e de abordagem para uma atividade intelectual, especialmente para uma Pesquisa". PASOLD, Cesar Luiz. Metodologia da pesquisa jurídica: teoria e prática, p. 61. 
VIVIANI, Rodrigo Andrade. O direito penal como instrumento destinado à proteção do meio ambiente: análise no contexto da constituição federal brasileira. Revista Eletrônica Direito e Política, Programa de Pós-Graduação Stricto Sensu em Ciência Jurídica da UNIVALI, Itajaí, v.11, n.2, 2o quadrimestre de 2016. Disponível em: www.univali.br/direitoepolitica - ISSN 1980-7791.

de uma nova dinâmica social e política, ultrapassando as fronteiras estatais, constituindo, assim, "ameaças globais supranacionais". Essas ameaças globais oriundas do processo industrial e tecnológico moderno, complementa Beck, "se precipitam sob a forma de ameaças à vida de plantas, animais e seres humanos". 6 Muitos desses novos riscos, outrossim, não seriam perceptíveis nem visíveis, de forma imediata, para os afetados, podendo se manifestar, por isso, num futuro nem sempre determinado. ${ }^{7}$

Diversos estudiosos, nesse particular, têm afirmado que o planeta Terra, em razão dos hábitos aderidos pelo próprio ser humano nas últimas décadas, está em estado de alerta.

Por isso, segundo o pensamento de Boff, "importa colocarmos em primeiro lugar Gaia, a Mãe Terra, e somente em seguida os seres humanos. Se não garantirmos a sustentabilidade do planeta acima de tudo, todas as demais iniciativas serão vãs e não se sustentarão". ${ }^{8}$

Pode-se dizer que, a partir da década de 60 do século passado, intensificaram-se, no seio da comunidade internacional, estudos e debates no sentido de se buscarem soluções e alternativas para a crise ecológica, potencializada pelas atividades impactantes causadas pelo ser humano, que estariam a provocar efeitos devastadores sobre o meio ambiente, podendo-se citar o aquecimento global e os danos sobre a camada de ozônio.

6 BECK, Ulrich. Sociedade de risco: rumo a uma outra modernidade. Tradução de Sebastião Nascimento. 2. ed. São Paulo: Editora 34, 2011, p. 16.

7 BECK, Ulrich. Sociedade de risco: rumo a uma outra modernidade, p. 32.

${ }^{8}$ BOFF, Leonardo. Sustentabilidade: $\mathbf{O}$ que é - $\mathbf{O}$ que não é. 2. ed. Petrópolis, RJ: Vozes, 2013. 
VIVIANI, Rodrigo Andrade. O direito penal como instrumento destinado à proteção do meio ambiente: análise no contexto da constituição federal brasileira. Revista Eletrônica Direito e Política, Programa de Pós-Graduação Stricto Sensu em Ciência Jurídica da UNIVALI, Itajaí, v.11, n.2, 2o quadrimestre de 2016. Disponível em: www.univali.br/direitoepolitica - ISSN 1980-7791.

Conforme Milaré, os Estados, no afã de incrementar o seu desenvolvimento econômico, têm explorado recursos naturais de forma indiscriminada, razão pela qual "A paisagem natural da Terra está cada vez mais ameaçada pelos riscos nucleares, pelo lixo atômico, pelos dejetos orgânicos, pela 'chuva ácida', pelas indústrias e pelo lixo químico". Desse modo, o enfrentamento dos problemas ambientais, nas palavras do autor, "é uma questão de vida ou morte, não apenas de animais e plantas, mas do próprio homem e do Planeta que o abriga". ${ }^{9}$

Neste cenário é que se realizou a Conferência das Nações Unidas sobre o Meio Ambiente, ocorrida em Estocolmo (Suécia) no ano de 1972, dando ensejo à denominada "Declaração do Meio Ambiente", também conhecida como "Declaração de Estocolmo". No referido documento, enumeraram-se 26 princípios fundamentais de proteção ambiental, que serviram de alicerce para a elaboração de textos constitucionais e legislativos em diversos Estados Democráticos de Direito, inclusive o capítulo reservado à proteção do meio ambiente previsto na Constituição Federal de 1988. ${ }^{10}$

Desse modo, pode-se dizer que o Direito Ambiental, tanto na seara internacional como no plano doméstico dos Estados, ganhou ênfase a partir da Declaração de Estocolmo de 1972, a qual, segundo Sarlet e Fensterseifer, "impulsionou, por todos os cantos do Planeta, o surgimento e aprimoramento das legislações nacionais em matéria ambiental, tanto em sede constitucional quanto infraconstitucional". ${ }^{11}$

\footnotetext{
9 MILARÉ, Édis. Direito do ambiente: a gestão ambiental em foco. 7. ed. São Paulo: Revista dos Tribunais, 2011, p. 66.

10 SILVA, José Afonso. Direito ambiental constitucional. 4. ed. São Paulo: Malheiros, 2003, p. 58-70.

11 SARLET, Ingo Wolfgang; FENSTERSEIFER, Tiago. Direito ambiental: Introdução, fundamentos e teoria geral. São Paulo: Saraiva, 2014, p. 383.
} 
VIVIANI, Rodrigo Andrade. O direito penal como instrumento destinado à proteção do meio ambiente: análise no contexto da constituição federal brasileira. Revista Eletrônica Direito e Política, Programa de Pós-Graduação Stricto Sensu em Ciência Jurídica da UNIVALI, Itajaí, v.11, n.2, 2o quadrimestre de 2016. Disponível em: www.univali.br/direitoepolitica - ISSN 1980-7791.

No Brasil, a Constituição Federal de 1988, na esteira das diretrizes estabelecidas pela Declaração de Estocolmo de 1972, enumerou, em seu texto, um arcabouço rigoroso de regras e princípios voltados à proteção do meio ambiente.

Nessa conjuntura, caberia indagar se o meio ambiente, por estar expressamente previsto na Constituição Federal de 1988, constituiria um direito fundamental, gozando, por conseguinte, de especial proteção.

De acordo com o art. 225, caput, da Constituição da República Federativa do Brasil de 1988, "Todos têm direito ao meio ambiente ecologicamente equilibrado, bem de uso comum do povo e essencial à sadia qualidade de vida, impondo-se ao Poder Público e à coletividade o dever de defendê-lo e preservá-lo para as presentes e futuras gerações". ${ }^{12}$

A doutrina brasileira, interpretando o citado preceito constitucional, tem adotado a posição de que a proteção ao meio ambiente, por estar relacionada à própria qualidade da vida humana, tratar-se-ia de um direito fundamental. ${ }^{13} \mathrm{O}$ Supremo Tribunal Federal, por meio de seu órgão pleno, no Mandado de Segurança n. 22.164, também já se manifestou pelo reconhecimento do meio ambiente como direito de terceira dimensão, inclusive destacando a importância de tal bem

12 BRASIL. Constituição da República Federativa do Brasil de 1988. Disponível em: <http://www.planalto.gov.br>. Acesso em: 14 fev. 2016.

13 Nesse sentido, ver: SILVA, José Afonso. Direito ambiental constitucional, 4. ed. São Paulo: Malheiros, 2003, p. 58-70; MILARÉ, Édis. Direito do ambiente: a gestão ambiental em foco, p. 1274/1275; SARLET, Ingo Wolfgang; FENSTERSEIFER, Tiago. Direito constitucional ambiental: Constituição, direitos fundamentais e proteção do meio ambiente, p. 50/51. 
VIVIANI, Rodrigo Andrade. O direito penal como instrumento destinado à proteção do meio ambiente: análise no contexto da constituição federal brasileira. Revista Eletrônica Direito e Política, Programa de Pós-Graduação Stricto Sensu em Ciência Jurídica da UNIVALI, Itajaí, v.11, n.2, 2o quadrimestre de 2016. Disponível em: www.univali.br/direitoepolitica - ISSN 1980-7791.

jurídico no processo de construção e desenvolvimento dos direitos humanos. ${ }^{14}$

Portanto, denota-se que o Constituição Federal brasileira conferiu especial proteção ao meio ambiente, havendo uma tendência na doutrina em considerá-lo como direito fundamental, especialmente em razão de sua vinculação com o direito à vida e a à saúde humana, não sendo demasiado relembrar a advertência de Loperena Rota, para quem "sin medio ambiente adecuado, no hay vida humana, ni sociedad, ni Derecho". 15

\section{O BEM JURÍdico COMO OBJETO de PROTEÇÃo DO DIREITO}

\section{PENAL}

O meio ambiente, em razão de sua significação social, passou a ser tutelado na perspectiva penal em diversos ordenamentos jurídicos, a exemplo do Brasil, o qual, por meio da Constituição Federal de 1988,

14 Transcreve-se o seguinte trecho da decisão do Supremo Tribunal Federal: "O direito à integridade do meio ambiente - típico direito de terceira geração - constitui prerrogativa jurídica de titularidade coletiva, refletindo, dentro do processo de afirmação dos direitos humanos, a expressão significativa de um poder atribuído, não ao indivíduo identificado em sua singularidade, mas, num sentido verdadeiramente mais abrangente, à própria coletividade social. Enquanto os direitos de primeira geração (direitos civis e políticos) - que compreendem as liberdades clássicas, negativas ou formais - realçam o princípio da liberdade e os direitos de segunda geração (direitos econômicos, sociais e culturais) - que se identificam com as liberdades positivas, reais ou concretas - acentuam o princípio da igualdade, os direitos de terceira geração, que materializam poderes de titularidade coletiva atribuídos genericamente a todas as formações sociais, consagram o princípio da solidariedade e constituem um momento importante no processo de desenvolvimento, expansão e reconhecimento dos direitos humanos, caracterizados, enquanto valores fundamentais indisponíveis, pela nota de uma essencial inexauribilidade" (BRASIL. Supremo Tribunal Federal. Mandado de Segurança n. 22.164/SP. Relator: Ministro Celso de Mello. Julgamento em 30/10/1995. Disponível em: www.stf.jus.br. Acesso em 10 mar. 2016).

15 "(...) sem meio ambiente adequado, não há vida humana, nem sociedade, nem Direito" (tradução livre). LOPERENA ROTA, Demetrio. Los principios del derecho ambiental. Madrid: Editorial Civitas, 1998, p. 52. 
VIVIANI, Rodrigo Andrade. O direito penal como instrumento destinado à proteção do meio ambiente: análise no contexto da constituição federal brasileira. Revista Eletrônica Direito e Política, Programa de Pós-Graduação Stricto Sensu em Ciência Jurídica da UNIVALI, Itajaí, v.11, n.2, 2o quadrimestre de 2016. Disponível em: www.univali.br/direitoepolitica - ISSN 1980-7791.

estabeleceu que as pessoas físicas e jurídicas podem ser responsabilizadas pela prática de infrações penais ambientais.

No entanto, antes de adentrar na discussão quanto à relevância da tutela penal em condutas lesivas ao meio ambiente, entende-se relevante traçar algumas considerações sobre a missão do Direito Penal em proteger bens jurídicos.

O Direito Penal, segundo a concepção predominante na doutrina, tem por objetivo a proteção de bens jurídicos fundamentais. ${ }^{16}$

No plano da dogmática penal, atribui-se a Birnbaum a formulação da expressão "bem jurídico". Para Cirino dos Santos, os bens jurídicos tutelados pelo Direito Penal, na sociedade contemporânea, corresponderiam aos valores relevantes para a vida humana individual ou coletiva. Esses bens jurídicos penais, segundo o penalista brasileiro, seriam formados por critérios de política-criminal alicerçados na respectiva Constituição, que representariam "realidades ou potencialidades necessárias ou úteis para a existência e desenvolvimento individual e social do ser humano". ${ }^{17}$

De acordo com Welzel, o Direito Penal teria uma função ético-social, mais precisamente a de "amparar os valores elementares da vida da comunidade". O Direito Penal, prossegue Welzel, tem por escopo resguardar determinados bens inerentes à vida da comunidade (os denominados bens jurídicos), como a própria vida, a liberdade, a saúde e a propriedade. Para que esses bens jurídicos sejam tutelados, o

16 BITENCOURT, Cezar Roberto. Tratado de Direito Penal. 15. ed. São Paulo: Saraiva, 2010, v.1, p. 37.

17 SANTOS, Juarez Cirino. Direito penal: parte geral. 3. ed. São Paulo: Curitiba: Lumen Juris, 2008, p. 5. 
VIVIANI, Rodrigo Andrade. O direito penal como instrumento destinado à proteção do meio ambiente: análise no contexto da constituição federal brasileira. Revista Eletrônica Direito e Política, Programa de Pós-Graduação Stricto Sensu em Ciência Jurídica da UNIVALI, Itajaí, v.11, n.2, 2o quadrimestre de 2016. Disponível em: www.univali.br/direitoepolitica - ISSN 1980-7791.

Direito Penal impõe condutas proibitivas que, se violadas, ensejam ao infrator a aplicação de uma pena, assegurando-se, desse modo, "a vigência dos valores positivos ético-sociais de ato, tais como o respeito pela vida alheia, a saúde, a liberdade, a propriedade e assim por diante". ${ }^{18}$

A missão primordial do Direito Penal, segundo o pensamento de Welzel, consiste em assegurar a preservação desses valores fundamentais (de conotação ético-social), ameaçando de pena àqueles que violarem tais preceitos elementares. Para o autor alemão, não se poderia dizer que a finalidade do Direito Penal se resumiria na proteção de bens jurídicos, porque "O simples amparo de bens jurídicos somente tem uma finalidade negativo-preventiva, policial-preventiva". Por isso, o papel precípuo do Direito Penal seria de natureza "positivo-ético-social", pois só assim se conseguiria concretizar a função protetora do bem jurídico. ${ }^{19}$

Nesse particular, transcreve-se seguinte linha de raciocínio de Welzel:

(...) o papel mais profundo que exerce o direito penal é de caráter positivo-ético-social, pois proibindo e sancionando o afastamento realmente manifestado dos valores fundamentais do pensamento jurídico, o Estado exterioriza do modo mais ostensivo de que dispõe, a validade inviolável destes valores positivos do ato, forma o juízo ético-social dos cidadãos e fortalece seu sentimento de permanente fidelidade ao direito (...)

Mediante a função ético-social mas ampla do direito penal, garante-se em forma compreensível e intensa a proteção dos bens jurídicos, do que com a simples idéia do arrimo desse bens. Os valores do ato de fidelidade, de obediência,

18 WELZEL, Hans. Direito penal. Tradução de Afonso Celso Rezende. 4. ed. Campinas: Editora Romana, 2004, p. 28/29.

19 WELZEL, Hans. Direito penal, p. 30. 
VIVIANI, Rodrigo Andrade. O direito penal como instrumento destinado à proteção do meio ambiente: análise no contexto da constituição federal brasileira. Revista Eletrônica Direito e Política, Programa de Pós-Graduação Stricto Sensu em Ciência Jurídica da UNIVALI, Itajaí, v.11, n.2, 2o quadrimestre de 2016. Disponível em: www.univali.br/direitoepolitica - ISSN 1980-7791.

de respeito pela pessoa e outros, são de maior alento e leva a uma maior amplitude de intenções de que o simples amparo desses bens. Não contemplam tão-somente o hoje ou o amanhã, mas sim o duradouro, o perene. ${ }^{20}$

Assim, na esteira do pensamento de Welzel, o Direito Penal, num primeiro momento, objetivaria fazer com que o cidadão se orientasse por valores éticos perante a sociedade, atuando, num segundo momento, com a imposição de pena para quem se portasse contrariamente ao ordenamento jurídico penal. Na visão de Welzel, segundo Bitencourt, a função primordial do Direito Penal é de caráter ético-social, sendo a função preventiva uma consequência lógica deste. ${ }^{21}$

Para Mir Puig, o Direito Penal não deve ser visto apenas como um conjunto de normas que prevêem delitos e penas para quem as violar. O Direito Penal, segundo o professor espanhol, teria um alcance mais amplo, pois objetivaria, também, fazer com que essas normas sejam dirigidas ao cidadão a não mais cometer o delito nelas previsto. Por isso, o Direito Penal seria constituído de normas que proíbem a prática do delito, impondo penas para quem desrespeitar a lei penal. ${ }^{22}$

De qualquer forma, Mir Puig sustenta que os bens jurídicos, para que mereçam proteção penal, devem revestir-se de importância fundamental. ${ }^{23}$

\footnotetext{
20 WELZEL, Hans. Direito penal, p. 30/31.

${ }^{21}$ BITENCOURT, Cezar Roberto. Tratado de Direito Penal, p. 38.

22 MIR PUIG, Santiago. Direito Penal: Fundamentos e teoria do delito. Tradução de Cláudia Viana Garcia e José Carlos Nobre Porciúncula Neto. São Paulo: Revista dos Tribunais, 2007, p. 35-38.

23 MIR PUIG, Santiago. Direito Penal: Fundamentos e teoria do delito, p. 96/97.
} 
VIVIANI, Rodrigo Andrade. O direito penal como instrumento destinado à proteção do meio ambiente: análise no contexto da constituição federal brasileira. Revista Eletrônica Direito e Política, Programa de Pós-Graduação Stricto Sensu em Ciência Jurídica da UNIVALI, Itajaí, v.11, n.2, 2o quadrimestre de 2016. Disponível em: www.univali.br/direitoepolitica - ISSN 1980-7791.

Portanto, a missão do Direito Penal tem por sustentáculo a proteção de bens jurídicos relevantes. A definição de bem jurídico, com efeito, não encontra uniformidade na doutrina, mas é possível afirmar que a sua utilização no Direito Penal fica condicionada à proteção de valores fundamentais e relevantes para uma sociedade, como a vida, a integridade física, a saúde e a propriedade.

Vale ressaltar que, em razão dos novos interesses inerentes à sociedade contemporânea, tem-se entendido que o bem jurídico penal não deveria limitar-se a proteger aqueles valores individuais típicos do Direito Penal tradicional, como a vida, a liberdade e a propriedade. O Direito Penal moderno tem ampliado o seu rol de proteção, incluindo, também, os bens jurídicos coletivos, que afetam a sociedade como um todo, dentre os quais se podem citar o meio ambiente, a saúde pública, a segurança coletiva, entre outros. ${ }^{24}$

Conforme esclarece Mir Puig, levando em consideração as transformações de valores advindas do capitalismo, os bens jurídicos tutelados pelo Direito Penal estariam se submetendo a uma mudança de paradigma. É dizer, o Direito Penal, na atualidade, estaria ampliando o seu raio de abrangência, preocupando-se, cada vez mais, com bens de alçada coletiva, que se revelariam de suma relevância para a sociedade, a exemplo do meio ambiente, ordem econômica, segurança social, direitos trabalhistas, entre outros. ${ }^{25}$

24 MUÑOZ CONDE, Francisco; GARCÍA ARÁN, Mercedes. Derecho penal: parte general. 9. ed. Valência: Tirant lo blanch, 2015, p. 64.

25 MIR PUIG, Santiago. Derecho penal: parte general. 7. ed. Barcelona: Editorial Reppertor, 2005, p. 167. 
VIVIANI, Rodrigo Andrade. O direito penal como instrumento destinado à proteção do meio ambiente: análise no contexto da constituição federal brasileira. Revista Eletrônica Direito e Política, Programa de Pós-Graduação Stricto Sensu em Ciência Jurídica da UNIVALI, Itajaí, v.11, n.2, 2o quadrimestre de 2016. Disponível em: www.univali.br/direitoepolitica - ISSN 1980-7791.

Todavia, é de ser ressaltado que essa proteção de bens jurídicos almejada pelo Direito Penal deve estar lastreada em critérios rígidos, a fim de que não perca a sua essência, com risco de comprometer a segurança social e estabilidade do ordenamento jurídico. Por isso, é imperativo que o legislador, na elaboração de tipos penais, atente-se aos princípios da intervenção mínima, subsidiariedade e fragmentariedade, a fim de que somente as condutas mais relevantes para a sociedade sejam tuteladas pelo Direito Penal (ultima ratio), cabendo aos demais ramos do Direito solucionarem as infrações de somenos importância social. ${ }^{26}$

\section{NECESSIDADE DA INTERVENÇÃo PENAL EM MATÉRIA AMBIENTAL}

Em razão da evolução tecnológica impulsionada pela Revolução Industrial do século XVIII, mas que atingiu o seu apogeu nas últimas décadas, pode-se dizer que a humanidade, atualmente, está vivenciando uma crise ecológica, o que levou a comunidade internacional a elaborar diversos tratados e convenções, no sentido de estabelecer diretrizes mínimas para a proteção do meio ambiente.

Atualmente, levando em consideração a preocupação da comunidade internacional com o meio ambiente, mormente em razão dos efeitos devastadores que o dano ambiental pode desencadear à saúde humana e à biodiversidade, muitos ordenamentos jurídicos passaram a utilizar o

\footnotetext{
${ }^{26}$ Vale lembrar, nesse sentido, que a função do Direito Penal, na visão de Claus Roxin, consistiria em "garantir a seus cidadãos uma existência pacífica, livre e socialmente segura, sempre e quando estas metas não possam ser alcançadas com outras medidas político-sociais que afetem em menor medida a liberdade dos cidadãos" (ROXIN, Claus.

A proteção de bens jurídicos como função do Direito Penal. Tradução de André Luís Callegari. 2. ed. Porto Alegre: Livraria do advogado, 2009, p. 17).
} 
VIVIANI, Rodrigo Andrade. O direito penal como instrumento destinado à proteção do meio ambiente: análise no contexto da constituição federal brasileira. Revista Eletrônica Direito e Política, Programa de Pós-Graduação Stricto Sensu em Ciência Jurídica da UNIVALI, Itajaí, v.11, n.2, 2o quadrimestre de 2016. Disponível em: www.univali.br/direitoepolitica - ISSN 1980-7791.

Direito Penal para a proteção de tal bem jurídico. ${ }^{27}$ Tratar-se-ia, assim, de dar consecução ao princípio ambiental da precaução, de extrema importância no âmbito internacional e doméstico (na maioria dos Estados de Democráticos de Direito), notadamente em razão dos efeitos maléficos (e muitas vezes imprevisíveis) inerentes à sociedade industrial contemporânea.

Em decorrência dos riscos advindos dos métodos tecnológicos e industriais atinentes à atividade econômica desempenhada nas últimas décadas, como reflexo do processo de globalização, o Direito Penal está se submetendo a uma mudança de paradigma, ampliando o seu raio de abrangência, de forma a intervir em interesses de natureza de natureza coletiva, a exemplo da economia, direitos dos consumidores e meio ambiente. Ou seja, as necessidades contemporâneas estariam a exigir uma mudança de paradigma do Direito Penal, de maneira que o seu âmbito de atuação não permanecesse restrito aos bens jurídicos de natureza individual (como a vida, liberdade, patrimônio, etc).

Na visão de Silva Sánchez, haveria uma tendência, na maioria dos ordenamentos jurídicos domésticos, em incrementar o âmbito de atuação do Direito Penal, formando-se novos tipos penais, bem como ampliando o rol de bens jurídicos que mereceriam a tutela penal. Essa nova tendência do Direito Penal, que o autor espanhol prefere

\footnotetext{
27 Nesse aspecto, é importante ressaltar que a Diretiva n. 2008/99/CE, do Parlamento Europeu e do Conselho da União Europeia, elaborada em 19 de novembro de 2008, em seu artigo 30, preconiza que os Estados-membros devem adotar as medidas necessárias para que determinadas condutas lesivas ao meio ambiente - na forma dolosa ou mediante culpa grave - sejam consideradas infrações penais (EUROPA. Diretiva n. 2008/99/CE, do Parlamento Europeu e do Conselho da União Europeia, de 19 de novembro de 2008. Disponível em: <http://eur-lex.europa.eu/legalcontent/PT/TXT/?uri=CELEX\%3A32008L0099>. Acesso em 17 de maio de 2016).
} 
VIVIANI, Rodrigo Andrade. O direito penal como instrumento destinado à proteção do meio ambiente: análise no contexto da constituição federal brasileira. Revista Eletrônica Direito e Política, Programa de Pós-Graduação Stricto Sensu em Ciência Jurídica da UNIVALI, Itajaí, v.11, n.2, 2o quadrimestre de 2016. Disponível em: www.univali.br/direitoepolitica - ISSN 1980-7791.

denominar de "expansionismo", refletir-se-ia na flexibilização de regras de imputação e na relativização de princípios de natureza criminal. ${ }^{28}$

Nesse contexto, Ferrajoli argumenta que os bens jurídicos fundamentais, atingidos pela criminalidade atual, não se restringiriam mais àqueles de natureza individual. É que o contexto da criminalidade atual, oriunda do processo de globalização, que o autor italiano prefere chamar de "criminalidade de poder", teria a potencialidade de afetar interesses mais graves e com maior dimensão, como a democracia, a paz e até mesmo o futuro do planeta. ${ }^{29}$

Dentre as formas de criminalidade de poder, Ferrajoli cita aquelas relacionadas com as infrações provenientes de grandes poderes econômicos transnacionais, a exemplo da corrupção e da apropriação de recursos naturais e outras lesões ao meio ambiente. Essa criminalidade - complementa o autor italiano -, por não contar com instrumentos eficazes do Direito Penal Internacional, contribuiria para o surgimento de poderes desregulados, estampados no pensamento predominantemente lucrativo. Ademais, segundo Ferrajoli, o mercado não seria mais dominado pelo Estado, mas, ao reverso, seriam as empresas quem protagonizariam os interesses econômicos, instalando-se em países mais vulneráveis e com legislação mais flexíveis na seara ambiental e trabalhista, que tolerariam com mais facilidade a prática de condutas devastadoras ao meio ambiente e à saúde da população. ${ }^{30}$

\footnotetext{
28 SILVA SÁNCHEZ, Jesús-Maria. La expansión del Derecho Penal: Aspectos de la política criminal en las sociedades postindustriales. 2. ed. Madrid: Civitas, 2001, p. 20.

${ }^{29}$ FERRAJOLI, Luigi. Criminalidad y globalización. Traduzido para o espanhol por Miguel Carbonell. Iter criminis - Revista de ciencias penales. Tlalpan (México), n. 1, terceira época, p. 74/75, ago/set. 2005.

${ }^{30}$ FERRAJOLI, Luigi. Criminalidad y globalización, p. 75.
} 
VIVIANI, Rodrigo Andrade. O direito penal como instrumento destinado à proteção do meio ambiente: análise no contexto da constituição federal brasileira. Revista Eletrônica Direito e Política, Programa de Pós-Graduação Stricto Sensu em Ciência Jurídica da UNIVALI, Itajaí, v.11, n.2, 2o quadrimestre de 2016. Disponível em: www.univali.br/direitoepolitica - ISSN 1980-7791.

Para Ferrajoli, a criminalidade de poder normalmente seria vinculada a fatores econômicos e políticos, e seria acobertada por poderes fortes e ocultos. Por isso, segundo o pensamento do autor, os protagonistas de crimes de significativa gravidade já não seriam mais aqueles indivíduos marginalizados socialmente (frequentemente envolvidos em delitos de natureza individual), mas sim detentores de poderes econômicos e políticos. A criminalidade econômica e organizada, assim, sustentaria e estimularia a delinquência tradicional. ${ }^{31}$

Assim, em virtude das transformações sociais e tecnológicas desencadeadas nas últimas décadas, com a sofisticação de novas condutas gravosas à sociedade, passou-se a redefinir as exigências do Direito Penal, para que este tutelasse novos valores, como, por exemplo, a economia, o interesse dos consumidores, o meio ambiente e, de forma geral, estratagemas praticados sob o manto do crime organizado.

No que toca propriamente ao meio ambiente, Esteve Pardo, ao fazer uma análise do sistema jurídico espanhol, conclui que a intervenção do Direito Penal, nessa matéria, decorreria de uma segunda reação do Direito. A primeira reação, segundo o professor espanhol, estaria no plano administrativo, em que a Administração Pública exerceria o protagonismo, não apenas no que se refere à intervenção preventiva, mas também repressiva, por meio da aplicação de sanções administrativas ${ }^{32}$.

31 FERRAJOLI, Luigi. Criminalidad y globalización, p. 76.

32 ESTEVE PARDO, José. Derecho del medio ambiente. 3. ed. Madrid: Marcial Pons, 2014, p. 107. 
VIVIANI, Rodrigo Andrade. O direito penal como instrumento destinado à proteção do meio ambiente: análise no contexto da constituição federal brasileira. Revista Eletrônica Direito e Política, Programa de Pós-Graduação Stricto Sensu em Ciência Jurídica da UNIVALI, Itajaí, v.11, n.2, 2o quadrimestre de 2016. Disponível em: www.univali.br/direitoepolitica - ISSN 1980-7791.

Num segundo momento, explica Pardo, algumas condutas em detrimento do meio ambiente já não deveriam ficar circunscritas tão somente ao âmbito administrativo, mas também à esfera penal. Isso ocorreria por diversas razões. A primeira delas decorreria da crescente valorização do meio ambiente nas denominadas sociedades pósindustriais, com o consequente repúdio social de condutas que atentem contra tal bem jurídico. Essa preocupação social refletiria na tipificação, na legislação penal, de algumas condutas contrárias ao meio ambiente, até como uma forma simbólica na proteção jurídica de bens jurídicos de maior dimensão social. ${ }^{33}$

A outra explicação, complementa Pardo, decorreria do próprio texto da Constituição Espanhola de 1978, que, em seu art. 45, estabeleceu que o infrator da norma ambiental poderá ser responsabilizado na seara administrativa e penal, sem embargo de sua obrigação de reparação do dano ambiental. ${ }^{34}$

O professor Esteve Pardo vislumbra uma terceira justificativa para a intervenção do Direito Penal no âmbito ambiental, que estaria alicerçada nas limitações e deficiências encontradas nas legislações administrativa e civil para resguardar o meio ambiente. Isso porque, nas esferas administrativa e civil, que priorizam as sanções patrimoniais (multas, indenizações e medidas reparatórias), os causadores de danos ambientais, com certa frequência, acabam transferindo as suas respectivas responsabilidades para as pessoas jurídicas das quais são titulares. Por isso, o Direito Penal poderia se mostrar uma via adequada

\footnotetext{
33 ESTEVE PARDO, José. Derecho del medio ambiente, p. 108.

34 ESTEVE PARDO, José. Derecho del medio ambiente, p. 107.
} 
VIVIANI, Rodrigo Andrade. O direito penal como instrumento destinado à proteção do meio ambiente: análise no contexto da constituição federal brasileira. Revista Eletrônica Direito e Política, Programa de Pós-Graduação Stricto Sensu em Ciência Jurídica da UNIVALI, Itajaí, v.11, n.2, 2ㅇquadrimestre de 2016. Disponível em: www.univali.br/direitoepolitica - ISSN 1980-7791.

para mitigar essa sensação de impunidade, uma vez que possibilitaria a atuação direta sobre os autores das condutas delituosas. ${ }^{35}$

Blanca Lozano Cutanda, seguindo essa mesma linha de raciocínio, sustenta que a utilização do Direito Penal para a proteção do meio ambiente, ainda que cercado de algumas críticas, constituiria uma imposição no ordenamento jurídico espanhol, em decorrência, sobretudo, do próprio texto estampado na Constituição Espanhola. Por isso, estar-se-ia deslocando o julgamento de certas infrações que antes eram reservadas à Administração Pública, fazendo com que o Poder Judiciário protagonizasse o julgamento de agressões ao meio ambiente de maior vulto. Vale dizer, nos últimos anos, na Espanha, em função de maior consciência social, estar-se-ia buscando a tipificação penal de condutas contrárias ao meio ambiente, que, no passado, eram reservadas à esfera administrativa. ${ }^{36}$

35 ESTEVE PARDO, José. Derecho del medio ambiente, p. 108. A redação do art. 45 da Constituição Espanhola de 1978, a propósito, é bastante similar com o texto reservado ao meio ambiente previsto na Constituição Federal Brasileira de 1988, conforme segue: "Artículo 45 - 1. Todos tienen el derecho a disfrutar de un medio ambiente adecuado para el desarrollo de la persona, así como el deber de conservarlo.2. Los poderes públicos velarán por la utilización racional de todos los recursos naturales, con el fin de proteger y mejorar la calidad de la vida y defender $y$ restaurar el medio ambiente, apoyándose en la indispensable solidaridad colectiva. 3. Para quienes violen lo dispuesto en el apartado anterior, en los términos que la ley fije se establecerán sanciones penales o, en su caso, administrativas, así como la obligación de reparar el daño causado" (ESPANHA. Constituição Espanhola. Disponível em: <http://www.boe.es/diario_boe/txt.php?id=BOE-A-1978-31229>. Acesso em: 23 jul. 2015).

36 LOZANO CUTANDA, Blanca; TURRILLAS, Juan-Cruz Alli. Administración y legislación ambiental. 7. ed. Madrid: Dykinson, 2013, p. 352/353. 
VIVIANI, Rodrigo Andrade. O direito penal como instrumento destinado à proteção do meio ambiente: análise no contexto da constituição federal brasileira. Revista Eletrônica Direito e Política, Programa de Pós-Graduação Stricto Sensu em Ciência Jurídica da UNIVALI, Itajaí, v.11, n.2, 2ㅇquadrimestre de 2016. Disponível em: www.univali.br/direitoepolitica - ISSN 1980-7791.

E, de fato, o Código Penal Espanhol de 1995, com as alterações promovidas pelas Leis Orgânicas n. 13/2003 e 5/2010, estabeleceu diversos tipos penais para a tutela do meio ambiente. ${ }^{37}$

A Constituição da República Federativa do Brasil de 1988, de forma semelhante à Constituição Espanhola, previu, em seu art. 225, e §30, o seguinte:

Art. 225 - Todos têm direito ao meio ambiente ecologicamente equilibrado, bem de uso comum do povo e essencial à sadia qualidade de vida, impondo-se ao Poder Público e à coletividade o dever de defendê-lo e preserválo para as presentes e futuras gerações.

\section{( ...)}

$\S 30$ As condutas e atividades consideradas lesivas ao meio ambiente sujeitarão os infratores, pessoas físicas ou jurídicas, a sanções penais e administrativas, independentemente da obrigação de reparar os danos causados. ${ }^{38}$

Como se vê, a Constituição Federal brasileira previu, em seu texto, um sistema tríplice de responsabilidade, permitindo que as pessoas físicas e jurídicas sejam sancionadas na esfera penal, administrativa e cível, ante a prática de condutas lesivas ao meio ambiente. Portanto, de forma similar à Constituição Espanhola de 1978, a Constituição Brasileira também estabeleceu a intervenção penal em matéria ambiental, tendo inovado, por outro lado, no que toca à responsabilidade penal das pessoas jurídicas.

37 Nesse sentido, conferir: LOZANO CUTANDA, Blanca; Turrilas, Juan-Cruz Alli. Administración y legislación ambiental, p. 364.

38 BRASIL. Constituição da República Federativa do Brasil de 1988. Disponível em: <http://www.planalto.gov.br>. Acesso em: 14 fev. 2016. 
VIVIANI, Rodrigo Andrade. O direito penal como instrumento destinado à proteção do meio ambiente: análise no contexto da constituição federal brasileira. Revista Eletrônica Direito e Política, Programa de Pós-Graduação Stricto Sensu em Ciência Jurídica da UNIVALI, Itajaí, v.11, n.2, 2o quadrimestre de 2016. Disponível em: www.univali.br/direitoepolitica - ISSN 1980-7791.

Nesse contexto, notadamente levando em consideração que o meio ambiente se trata de um direito fundamental (segundo pensamento predominante entre os autores brasileiros), é possível concluir que a criminalização de condutas lesivas ao meio ambiente, no Brasil, se trata, em verdade, de um imperativo constitucional.

Por isso, a intervenção do Direito Penal na esfera ambiental, ao menos no plano nacional, não se trata apenas de uma necessidade calcada na crise ecológica que permeia a sociedade pós-industrial contemporânea. Isso porque o seu fundamento encontra resguardo no próprio texto constitucional, que estabeleceu, de forma expressa, que as pessoas físicas e jurídicas poderão se submeter à sanção penal acaso pratiquem condutas lesivas ao meio ambiente.

É certo que existe uma corrente teórica criticando a utilização do Direito Penal para a solução de conflitos na seara ambiental. Essa intervenção, segundo Antonio García-Pablos de Molina, estaria atrelada à "função promocional" do Direito Penal, que, em sua visão, seria ilegítima, sobretudo porque seria influenciada pelo poder político. É dizer, por meio de função promocional dos crimes ambientais, estar-se-ia trazendo para a ciência penal condutas que poderiam ser solucionadas na via administrativa, quiçá para atender a determinados setores da sociedade. ${ }^{39}$ Silva Sánchez, por sua vez, salienta que a criminalização ambiental, na Espanha, revestir-se-ia, em alguns tipos penais, de uma

\footnotetext{
39 MOLINA, Antonio García-Pablos; GOMES, Luiz Flávio. Direito Penal: Fundamentos e limites do Direito Penal. 3. ed. São Paulo: Revista dos Tribunais, 2012, p. 195/196 e 207.
} 
VIVIANI, Rodrigo Andrade. O direito penal como instrumento destinado à proteção do meio ambiente: análise no contexto da constituição federal brasileira. Revista Eletrônica Direito e Política, Programa de Pós-Graduação Stricto Sensu em Ciência Jurídica da UNIVALI, Itajaí, v.11, n.2, 2o quadrimestre de 2016. Disponível em: www.univali.br/direitoepolitica - ISSN 1980-7791.

"função promocional", uma vez que se estaria tencionado gerar, na sociedade, uma "ética ecológica" até então inexistente. ${ }^{40}$

Contudo, considerando que o meio ambiente, na perspectiva do texto constitucional brasileiro, se trata de um direito fundamental, é necessário que sejam adotados todos os mecanismos para que a sua proteção (inclusive no prisma penal) possa ser efetivamente concretizada. Aliás, vale lembrar que a criminalização ambiental se trata de um mandamento expresso do constituinte, nos termos do art. 225, $\S 30$, da Constituição Federal de 1988.

Nesse rumo, é possível concluir que o meio ambiente se trata de um bem jurídico que reclama, de forma inexorável, a intervenção do Direito Penal.

Aliás, os bens jurídicos, na concepção de Claus Roxin, poderiam ser resumidos como "circunstâncias reais dadas ou finalidades necessárias para uma vida digna e livre, que garanta todos os direitos humanos e civis de cada um na sociedade ou para o funcionamento de um sistema estatal que se baseia nestes objetivos". ${ }^{41}$

E o meio ambiente, por estar atrelado à própria qualidade e existência da vida humana, estaria, assim, na condição de bem jurídico a ser tutelado pelo Direito Penal, ainda que tal ramo jurídico só esteja legitimado a intervir em ultima ratio, isto é, quando outros ramos do Direito não se revelarem suficientes para a solução do conflito, na

40 SILVA SÁNCHEZ, Jesús-María. Aproximação ao Direito Penal contemporâneo. Tradução de Roberto Barbosa Alves. São Paulo: Revista dos Tribunais, 2011, p. 456.

41 ROXIN, Claus. A proteção de bens jurídicos como função do Direito Penal, p. $18 / 19$. 
VIVIANI, Rodrigo Andrade. O direito penal como instrumento destinado à proteção do meio ambiente: análise no contexto da constituição federal brasileira. Revista Eletrônica Direito e Política, Programa de Pós-Graduação Stricto Sensu em Ciência Jurídica da UNIVALI, Itajaí, v.11, n.2, 2o quadrimestre de 2016. Disponível em: www.univali.br/direitoepolitica - ISSN 1980-7791.

esteira dos princípios da intervenção mínima, subsidiariedade e fragmentariedade.

\section{O DiREITO PENAL COMO INSTRUMENTO DESTINAdo À PROTEÇÃo do MEIO AMBIENTE: ANÁlise NO CONTEXTO do ORDENAMENTO JURÍDICO BRASILEIRO}

A intervenção do Direito Penal em matéria ambiental, conforme se pontuou no decorrer deste trabalho, se trata de um imperativo imposto pela própria Constituição Federal Brasileira de 1988, a qual, a propósito, conferiu ao meio ambiente a estatura de norma fundamental. ${ }^{42}$

A Constituição Federal de 1988, nesse particular, trouxe relevante inovação, ao permitir que não apenas as pessoas físicas possam ser responsabilizadas penalmente por crimes ambientais, mas também a própria pessoa jurídica.

No Brasil, a maioria dos crimes ambientais estão previstos na Lei Federal n. 9.605/98, a qual, aliás, regulamentou a responsabilidade penal da pessoa jurídica de que trata a Constituição Federal de $1988^{43}$. Porém, anteriormente à edição da Lei Federal n. 9.605/98 (que atualmente regula a maioria dos tipos penais na seara ambiental), já existiam outros diplomas normativos prevendo a tipificação de crimes

\footnotetext{
42 Nesse sentido, conferir art. 225, §3, da Constituição da República Federativa do Brasil de 1988.

43 BRASIL. Lei n. 9.605, de 12 de fevereiro de 1998. Dispõe sobre as sanções penais e administrativas derivadas de condutas e atividades lesivas ao meio ambiente, e dá outras providências. Disponível em: <http://www.planalto.gov.br>. Acesso em: 14 fev. 2016.
} 
VIVIANI, Rodrigo Andrade. O direito penal como instrumento destinado à proteção do meio ambiente: análise no contexto da constituição federal brasileira. Revista Eletrônica Direito e Política, Programa de Pós-Graduação Stricto Sensu em Ciência Jurídica da UNIVALI, Itajaí, v.11, n.2, 2o quadrimestre de 2016. Disponível em: www.univali.br/direitoepolitica - ISSN 1980-7791.

ambientais, embora fossem dispersos e, em certo sentido, tivessem redação paradoxal. ${ }^{44}$

Milaré, ao examinar a estrutura tipológica prevista na Lei Federal n. $9.605 / 98$, conclui que o bem jurídico tutelado pela norma penal é o meio ambiente em sua dimensão global, abrangendo as seguintes ramificações: I) meio ambiente natural, que abarca o solo, a água, o ar atmosférico, a flora e a fauna; II) meio ambiente cultural, que é integrado pelo patrimônio histórico, artístico, turístico, paisagístico, arqueológico, entre outros; III) meio ambiente artificial, que tem pertinência com o espaço urbano construído, abrangendo, assim, ruas, praças, áreas verdes, bem como demais edificações e equipamentos urbanísticos. ${ }^{45}$

Cabe enfatizar que, em razão da amplitude do conceito envolvendo o meio ambiente, é recomendável cautela na elaboração de tipos penais, procurando-se tipificar aquelas condutas que, diretamente ou indiretamente, afetem a qualidade de vida humana e os bens mais relevantes para a preservação do meio ambiente (como o solo, flora, fauna, ar atmosférico e água, bem como patrimônio histórico, paisagístico, arqueológico, cultural, ente outros).

A Lei n. 9.605/98, regulamentando o texto constitucional brasileiro, previu, em seu texto, um arcabouço de tipos penais tratando de condutas contrárias ao meio ambiente, protegendo a flora, a fauna, o ar

44 Nesse sentido, conferir: MARCHESAN, Ana Maria Moreira; STEIGLEDER, Annelise Monteiro (Orgs.). Crimes ambientais: Comentários à Lei 9.605/98. Porto Alegre: Livraria do advogado, 2013, p. 17.

45 MILARÉ, Édis. Direito do ambiente: a gestão ambiental em foco, p. 1283. 
VIVIANI, Rodrigo Andrade. O direito penal como instrumento destinado à proteção do meio ambiente: análise no contexto da constituição federal brasileira. Revista Eletrônica Direito e Política, Programa de Pós-Graduação Stricto Sensu em Ciência Jurídica da UNIVALI, Itajaí, v.11, n.2, 2ㅇ quadrimestre de 2016. Disponível em: www.univali.br/direitoepolitica - ISSN 1980-7791.

atmosférico, o patrimônio histórico e cultural, bem outros valores ecológicos ${ }^{46}$.

A referida legislação criminal ambiental, entrementes, foi alvo de críticas pela doutrina, sobretudo porque estabeleceu diversos tipos penais de "perigo concreto" e de "perigo abstrato", e não somente tipos de dano (que seria a regra no Direito Penal). ${ }^{47}$ Mas a fixação de crimes de perigo, em se tratando de meio ambiente, é justificada, haja vista a natureza protetiva do Direito Penal ambiental, lastreada nos princípios da prevenção e da precaução. Sob outro prisma, há quem sustente que alguns tipos penais de "perigo abstrato", previstos na Lei n. 9.605/98, poderiam, em algumas situações específicas, ter a sua aplicação relativizada, em homenagem aos princípios da ofensividade e da proporcionalidade. ${ }^{48}$

De qualquer forma, considerando que uma das finalidades do Direito Penal ambiental é proteger o meio ambiente (numa perspectiva preventiva), seria justificada a adoção de tipos penais de perigo, até

\footnotetext{
46 BRASIL. Lei n. 9.605, de 12 de fevereiro de 1998. Dispõe sobre as sanções penais e administrativas derivadas de condutas e atividades lesivas ao meio ambiente, e dá outras providências. Disponível em: <http://www.planalto.gov.br>. Acesso em: 14 fev. 2016.

47 Vale lembrar que os crimes de dano, para a sua consumação, dependem da efetiva lesão ao bem jurídico tutelado pela norma. Os crimes de perigo, por sua vez, são aqueles que se consumam com a exposição de perigo para o bem jurídico, prescindindo-se de um dano efetivo. No crime de perigo concreto, segundo Bitencourt, "deve ser demonstrada a situação de risco ocorrido pelo bem jurídico tutelado pela protegido", enquanto o crime de perigo abstrato "é presumido juris et de jure" (BITENCOURT, Cezar Roberto. Tratado de Direito Penal, p. 255).

48 FREITAS, Flávio Avellar Silva; RIBEIRO, Luiz Gustavo Gonçalves. O crivo da proporcionalidade e a colisão entre o princípio constitucional da precaução sob a perspectiva da tipificação de delitos de perigo abstrato na Lei n. 9.605/98 e o princípio constitucional da ofensividade. In: COSTA, Beatriz Souza; REZENDE, Elcio Nacur (Orgs). Temas essenciais em direito ambiental: Um diálogo internacional. Rio de Janeiro: Lumen Juris, 2014, p. 257-275.
} 
VIVIANI, Rodrigo Andrade. O direito penal como instrumento destinado à proteção do meio ambiente: análise no contexto da constituição federal brasileira. Revista Eletrônica Direito e Política, Programa de Pós-Graduação Stricto Sensu em Ciência Jurídica da UNIVALI, Itajaí, v.11, n.2, 2o quadrimestre de 2016. Disponível em: www.univali.br/direitoepolitica - ISSN 1980-7791.

mesmo levando em consideração o desconhecimento da potencialidade de todos os riscos provocados pela sociedade pós-industrial (cabendo aludir, aqui, o princípio da precaução). Outrossim, a importância da utilização dos tipos penais de perigo abstrato para a proteção do meio ambiente, conforme esclarece Ana Paula Nogueira da Cruz, evitaria a prática de condutas que poderiam atingi-lo, além de reforçar a confiança da norma ambiental, "de modo a indicar a relevância do bem para o ordenamento jurídico que não tolera sequer riscos graves ao meio ambiente". 49

Com relação à crítica de que muitos tipos penais previstos na Lei $\mathrm{n}$. 9.605/98 constituiriam norma penal em branco (que seriam aqueles tipos penais que, para a sua concretização, dependeriam da complementação e esclarecimento de outra legislação ou ato normativo), entende-se, também, que não haveria incoerência na sua utilização, especialmente levando em consideração a finalidade preventiva buscada pelo Direito Penal ambiental. Sob este prisma, Édis Milaré assevera que "tal prática decorre do caráter complexo, técnico e multidisciplinar das questões relativas ao meio ambiente e à sua estreita relação com a legislação administrativa". 50

É certo que o Direito Penal não tem o condão de solucionar todas as mazelas e conflitos oriundos de agressões que afetem o meio ambiente, até porque este se trata de um bem jurídico difuso com definição demasiadamente ampla. Além disso, como forma se assegurar o valor

49 CRUZ, Ana Paula Fernandes Nogueira. A responsabilidade penal da pessoa física, a culpabilidade e as excludentes em matéria penal ambiental (artigo 20). In: MARCHESAN, Ana Maria Moreira; STEIGLEDER, Annelise Monteiro (Orgs.). Crimes ambientais: Comentários à Lei 9.605/98. Porto Alegre: Livraria do advogado, 2013, p. 48.

${ }^{50}$ MILARÉ, Édis. Direito do ambiente: a gestão ambiental em foco, p. 1281. 
VIVIANI, Rodrigo Andrade. O direito penal como instrumento destinado à proteção do meio ambiente: análise no contexto da constituição federal brasileira. Revista Eletrônica Direito e Política, Programa de Pós-Graduação Stricto Sensu em Ciência Jurídica da UNIVALI, Itajaí, v.11, n.2, 2o quadrimestre de 2016. Disponível em: www.univali.br/direitoepolitica - ISSN 1980-7791.

da sustentabilidade em sua plenitude, é imperativo que o Estado (especialmente os Poderes Executivo e Legislativo) implemente políticas públicas efetivas tendentes a preservar o meio ambiente, inclusive investindo na educação ambiental.

Nesse desiderato, conforme Lozano Cutanda, as políticas de proteção ao meio ambiente, em princípio, deveriam priorizar a adoção de medidas preventivas, como, por exemplo, investindo na promoção de educação ambiental. As medidas punitivas, segundo a autora espanhola, deveriam ser adotadas nos casos em que a lesão ao meio ambiente já estivesse concretizada, ou, quiçá, quando a reparação do dano ambiental fosse inviável ou de difícil realização. Mas isso não significaria que o Direito Penal não deveria intervir em matéria ambiental, até porque a punição criminal, em verdade, contribuiria para garantir o cumprimento de normas e medidas de proteção ambiental, revelando, assim, a sua função de prevenção. 51

O caráter preventivo do Direito Penal ambiental, no dizer de Lozano Cutanda, poderia ser resumido em duas vertentes: A primeira delas consistira na função "preventiva geral", no sentido de desestimular a prática da infração penal ambiental (para aqueles que tencionassem lesar o meio ambiente); A segunda vertente consistiria na função "preventiva especial", no sentido de que o indivíduo sancionado penalmente não mais viesse a reincidir na prática do ilícito penal ambiental. ${ }^{52}$

51 LOZANO CUTANDA, Blanca; TURRILLAS, Juan-Cruz Alli. Administración y legislación ambiental, p. 351/352.

52 LOZANO CUTANDA, Blanca; TURRILLAS, Juan-Cruz Alli. Administración y legislación ambiental, p. 352. 
VIVIANI, Rodrigo Andrade. O direito penal como instrumento destinado à proteção do meio ambiente: análise no contexto da constituição federal brasileira. Revista Eletrônica Direito e Política, Programa de Pós-Graduação Stricto Sensu em Ciência Jurídica da UNIVALI, Itajaí, v.11, n.2, 2o quadrimestre de 2016. Disponível em: www.univali.br/direitoepolitica - ISSN 1980-7791.

Muñoz Conde, Peregrín e García Álvarez acrescentam, ainda, que a intervenção penal na seara ambiental, além dos efeitos preventivos gerais e especiais, serviria também para fortalecer e ampliar a consciência social a respeito dos malefícios causados à humanidade por ataques ao meio ambiente. ${ }^{53}$

Sobre a importância da intervenção penal na proteção do bem jurídico meio ambiente, Sirvinskas leciona que:

O meio ambiente não tem pátria. Ele é de cada um, individualmente, e, ao mesmo tempo, de todos. Sua proteção não deve restringir-se a uma ou a várias pessoas de um mesmo país, mas, sim, a todos os países. Um crime ambiental poderá repercutir em diversos países do mundo, como, por exemplo, um desastre nuclear ou a poluição de um rio que corta alguns países.

Por esse motivo é que a tutela penal do meio ambiente passa a ser tão importante, pois o bem jurídico protegido é mais amplo do que o bem protegido em outros tipos penais $^{54}$

Diante desse panorama, levando em consideração o mandamento insculpido no texto constitucional brasileiro, e tendo em vista os postulados estabelecidos na Conferência de Estocolmo de 1972 (e demais documentos internacionais editados posteriormente), extrai-se que a intervenção penal na esfera ambiental, além de necessária, cumpre um papel indispensável na proteção do meio ambiente, concretizando, assim, as funções da prevenção geral e especial do Direito Penal.

53 MUÑOZ CONDE, Francisco; PEREGRÍN, Carmen López; ÁLVARES, Pastora García. Manual de derecho penal medioambiental, p. 66/67.

${ }^{54}$ SIRVINSKAS, Luís Paulo. Manual de direito ambiental. 9. ed. São Paulo: Saraiva, 2011, p. 607. 
VIVIANI, Rodrigo Andrade. O direito penal como instrumento destinado à proteção do meio ambiente: análise no contexto da constituição federal brasileira. Revista Eletrônica Direito e Política, Programa de Pós-Graduação Stricto Sensu em Ciência Jurídica da UNIVALI, Itajaí, v.11, n.2, 2o quadrimestre de 2016. Disponível em: www.univali.br/direitoepolitica - ISSN 1980-7791.

Em outras palavras, a criminalização de condutas lesivas ao meio ambiente não se restringe ao caráter repressivo da norma penal, por meio da respectiva sanção penal. Essa criminalização, por certo, reveste-se, também, de um efeito preventivo, que, nas palavras de Ana Paula Fernandes Nogueira da Cruz, abrange não só a função de prevenção geral e especial do Direito Penal, mas principalmente a função de educação ambiental. ${ }^{55}$

A educação ambiental buscada pela Lei n. $9.605 / 98$ se refletiria no escopo pedagógico das penalidades restritivas de direitos (lembrando-se que a aludida legislação priorizou tais sanções restritivas de direitos, em substituição às penas privativas de liberdade), bem como outros benefícios de ordem penal e processual penal, como os institutos despenalizadores previstos na Lei n. 9.099/95 (transação penal e suspensão condicional do processo). ${ }^{56}$

O caráter preventivo da legislação criminal ambiental, ademais, objetivaria incutir na sociedade uma postura pautada na ética ambiental. ${ }^{57}$

Sob outro prisma, a intervenção penal ambiental, em conformidade com o pensamento de Schünemann, mostrar-se-ia necessária para proteger os recursos naturais que seriam essenciais à manutenção da qualidade de vida das futuras gerações. O autor alemão, nesse desiderato, critica a linha teórica desenvolvida por alguns penalistas da Universidade de

\footnotetext{
55 CRUZ, Ana Paula Fernandes Nogueira. A responsabilidade penal da pessoa física, a culpabilidade e as excludentes em matéria penal ambiental (artigo $2^{\circ}$ ), p. 31.

56 CRUZ, Ana Paula Fernandes Nogueira. A responsabilidade penal da pessoa física, a culpabilidade e as excludentes em matéria penal ambiental (artigo $2^{\circ}$ ), p. 31.

57 CRUZ, Ana Paula Fernandes Nogueira. A responsabilidade penal da pessoa física, a culpabilidade e as excludentes em matéria penal ambiental (artigo $2^{\circ}$ ), p. 32.
} 
VIVIANI, Rodrigo Andrade. O direito penal como instrumento destinado à proteção do meio ambiente: análise no contexto da constituição federal brasileira. Revista Eletrônica Direito e Política, Programa de Pós-Graduação Stricto Sensu em Ciência Jurídica da UNIVALI, Itajaí, v.11, n.2, 2ㅇquadrimestre de 2016. Disponível em: www.univali.br/direitoepolitica - ISSN 1980-7791.

Frankfurt (dentre os quais se destacam Hassemer), os quais, seguindo uma visão antropocêntrica, defenderiam que a tipificação penal, na seara ambiental, deveria vincular-se a uma lesão aos indivíduos afetados. Na visão de Schünemann, o meio ambiente deveria ser tutelado de forma autônoma pelo Direito Penal, adotando, assim, uma postura voltada ao ecocentrismo moderado. ${ }^{58}$

Os instrumentos à disposição do Direito Civil e Administrativo, por outro lado, não têm alcançado, em muitos casos, o efeito almejado, sobretudo por não disporem de meios mais eficazes e inibidores para a punição dos causadores de danos ambientais. ${ }^{59}$

Por isso, a intervenção penal na esfera ambiental, no ordenamento jurídico brasileiro, não trata apenas de cumprir um mandamento constitucional, pois se mostra, também, um instrumento inexorável para proteger o meio ambiente, concretizando-se, assim, os princípios da prevenção e da precaução, que norteiam o Direito Ambiental no plano internacional e doméstico.

58 SCHÜNEMANN, Bernd. Temas actuales y permanentes del Derecho penal después del milenio. Madrid: Tecnos, 2002, p. 60/61 e 220/221.

59 Essa, a propósito, constitui uma das razões que ensejaram a edição da Diretiva $n$. 2008/99/CE, do Parlamento Europeu e do Conselho da União Europeia, que estabelece que os Estados-membros devem adotar as medidas necessárias para que determinadas condutas lesivas ao meio ambiente consideradas infrações penais nas respectivas legislações domésticas. No preâmbulo da citada Diretiva, consignou-se que "A experiência tem revelado que os actuais regimes de sanções não têm sido suficientes para garantir a observância absoluta da legislação sobre protecção do ambiente. Esta observância pode e deverá ser reforçada através da previsão de sanções penais que reflictam uma desaprovação social qualitativamente diferente das sanções administrativas ou dos mecanismos de indemnização do direito civil". (EUROPA. Diretiva n. 2008/99/CE, do Parlamento Europeu e do Conselho da União Europeia, de 19 de novembro de 2008. Disponível em: <http://eurlex.europa.eu/legal-content/PT/TXT/?uri=CELEX\%3A32008L0099>. Acesso em 02 jul. 2016). 
VIVIANI, Rodrigo Andrade. O direito penal como instrumento destinado à proteção do meio ambiente: análise no contexto da constituição federal brasileira. Revista Eletrônica Direito e Política, Programa de Pós-Graduação Stricto Sensu em Ciência Jurídica da UNIVALI, Itajaí, v.11, n.2, 2o quadrimestre de 2016. Disponível em: www.univali.br/direitoepolitica - ISSN 1980-7791.

\section{CONSIDERAÇÕES FINAIS}

Conforme colocado neste estudo, a preocupação com o meio ambiente intensificou-se, no plano normativo, a partir da Conferência de Estocolmo realizada no ano de 1972, sobretudo ante o reconhecimento de que o planeta Terra estaria em estado de alerta, mercê das atividades impactantes causadas pelo próprio ser humano.

A sociedade contemporânea, ademais, estaria marcada por riscos, decorrentes da atividade industrial e tecnológica impulsionada nas últimas décadas, que teriam a potencialidade de comprometer a biodiversidade e a própria sobrevivência humana.

Por outro lado, as normas de caráter civil e administrativo não estariam conseguindo cumprir o seu desiderato na repressão e proteção ao meio ambiente, o que levou a se intensificar o debate social para que o Direito Penal pudesse intervir na seara ambiental.

A intervenção do Direito Penal no meio ambiente, a propósito, tem sido albergada em diversos textos constitucionais de Estados Democráticos de Direito, dentre eles o Brasil, que, no bojo do art. 225, §3, da Constituição Federal de 1988, previu, de forma expressa, que as pessoas físicas e jurídicas poderiam ser sancionadas penalmente ante a prática de conduta lesiva ao meio ambiente, sem embargo da responsabilização na esfera cível e administrativa.

O meio ambiente, outrossim, tem sido interpretado pela doutrina brasileira como um bem jurídico alçado à categoria de norma fundamental, devendo gozar, assim, de primazia na sua aplicação, como 
VIVIANI, Rodrigo Andrade. O direito penal como instrumento destinado à proteção do meio ambiente: análise no contexto da constituição federal brasileira. Revista Eletrônica Direito e Política, Programa de Pós-Graduação Stricto Sensu em Ciência Jurídica da UNIVALI, Itajaí, v.11, n.2, 2o quadrimestre de 2016. Disponível em: www.univali.br/direitoepolitica - ISSN 1980-7791.

sói ocorrer com os demais direitos fundamentais encampados pelo constituinte.

Diante desse panorama, extrai-se que a intervenção do Direito Penal para a tutela do meio ambiente, no ordenamento jurídico brasileiro, constitui uma imposição estabelecida pela própria Constituição Federal de 1988 e, por isso, caberia ao legislador adotar todos os mecanismos para que se implementasse o mandamento constitucional, o que fora feito pela Lei Federal n. 9.605/98.

A Lei n. 9.605/98, não obstante alvo de crítica por determinado setor da doutrina (notadamente por ter previsto expressiva quantidade de tipos penais de "perigo", sem a necessidade de demonstração do dano, e "normas penais em branco", as quais dependeriam de complemento da legislação administrativa), seguiu a diretriz do texto constitucional brasileiro, sobretudo porque o meio ambiente, além de constituir um direito fundamental (de terceira dimensão), é essencial para que assegure a preservação da vida humana em sua plenitude.

Desse modo, em razão dos riscos advindos da atividade industrial e tecnológica, é possível concluir que o Direito Penal, na esfera ambiental, se revela um instrumento indispensável para proteger o meio ambiente, na esteira dos princípios da precaução e da prevenção. Essa imprescindibilidade é reforçada em razão dos anseios da Constituição Federal de 1988, que conferiu especial relevância à proteção do meio ambiente.

Merece destaque, nesse sentido, a finalidade preventiva exercida pelo Direito Penal, que, além de servir de estímulo para a preservação do 
VIVIANI, Rodrigo Andrade. O direito penal como instrumento destinado à proteção do meio ambiente: análise no contexto da constituição federal brasileira. Revista Eletrônica Direito e Política, Programa de Pós-Graduação Stricto Sensu em Ciência Jurídica da UNIVALI, Itajaí, v.11, n.2, 2o quadrimestre de 2016. Disponível em: www.univali.br/direitoepolitica - ISSN 1980-7791.

meio ambiente (em razão do efeito inibidor de suas sanções), se revela um importante instrumento de conscientização social.

Finalmente, não obstante a amplitude do conceito envolvendo o meio ambiente, verificou-se, neste estudo, que inexistem empecilhos para que tal bem jurídico seja tutelado de forma autônoma pelo Direito Penal, até mesmo para assegurar os recursos naturais necessários à preservação e continuidade da vida humana.

\section{REFERÊNCIAS DAS FONTES CITADAS}

BECK, Ulrich. Sociedade de risco: rumo a uma outra modernidade. Tradução de Sebastião Nascimento. São Paulo: Editora 34, 2011.

BITENCOURT, Cezar Roberto. Tratado de Direito Penal. 15. ed. São Paulo: Saraiva, 2010, v.1.

BOFF, Leonardo. Sustentabilidade: O que é - O que não é. 2. ed. Petrópolis, RJ: Vozes, 2013.

BRASIL. Constituição da República Federativa do Brasil de 1988. Disponível em: <http://www.planalto.gov.br>. Acesso em: 14 fev. 2016.

BRASIL. Lei n. 9.605, de 12 de fevereiro de 1998. Dispõe sobre as sanções penais e administrativas derivadas de condutas e atividades lesivas ao meio ambiente, e dá outras providências. Disponível em: <http://www.planalto.gov.br>. Acesso em: 14 fev. 2016.

BRASIL. Supremo Tribunal Federal. Mandado de Segurança n. 22.164/SP. Relator: Ministro Celso de Mello. Julgamento em 30/10/1995. Disponível em: www.stf.jus.br. Acesso em 10 mar. 2016. 
VIVIANI, Rodrigo Andrade. O direito penal como instrumento destinado à proteção do meio ambiente: análise no contexto da constituição federal brasileira. Revista Eletrônica Direito e Política, Programa de Pós-Graduação Stricto Sensu em Ciência Jurídica da UNIVALI, Itajaí, v.11, n.2, 2o quadrimestre de 2016. Disponível em: www.univali.br/direitoepolitica - ISSN 1980-7791.

CRUZ, Ana Paula Fernandes Nogueira. A responsabilidade penal da pessoa física, a culpabilidade e as excludentes em matéria penal ambiental (artigo 20). In: MARCHESAN, Ana Maria Moreira; STEIGLEDER, Annelise Monteiro (Orgs.). Crimes ambientais: Comentários à Lei 9.605/98. Porto Alegre: Livraria do advogado, 2013, p. 27-53.

ESPANHA. Constituição Espanhola. Disponível em: <http://www.boe.es/diario_boe/txt.php?id=BOE-A-1978-31229>.

Acesso em: 14 fev. 2016.

ESTEVE PARDO, José. Derecho del medio ambiente. 3. ed. Madrid: Marcial Pons, 2014.

EUROPA. Diretiva n. 2008/99/CE, do Parlamento Europeu e do Conselho da União Europeia, de 19 de novembro de 2008. Disponível em: $<$ http://eur-lex.europa.eu/legal-

content/PT/TXT/?uri=CELEX\%3A32008L0099>. Acesso em 02 jul. 2016. FERRAJOLI, Luigi. Criminalidad y globalización. Traduzido para o espanhol por Miguel Carbonell. Iter criminis - Revista de ciencias penales. Tlalpan (México), n. 1, terceira época, p. 71-88, ago/set. 2005.

FREITAS, Flávio Avellar Silva; RIBEIRO, Luiz Gustavo Gonçalves. O crivo da proporcionalidade e a colisão entre o princípio constitucional da precaução sob a perspectiva da tipificação de delitos de perigo abstrato na Lei n. 9.605/98 e o princípio constitucional da ofensividade. In: COSTA, Beatriz Souza; REZENDE, Elcio Nacur (Orgs). Temas essenciais em direito ambiental: Um diálogo internacional. Rio de Janeiro: Lumen Juris, 2014, p. 243-277. 
VIVIANI, Rodrigo Andrade. O direito penal como instrumento destinado à proteção do meio ambiente: análise no contexto da constituição federal brasileira. Revista Eletrônica Direito e Política, Programa de Pós-Graduação Stricto Sensu em Ciência Jurídica da UNIVALI, Itajaí, v.11, n.2, 2o quadrimestre de 2016. Disponível em: www.univali.br/direitoepolitica - ISSN 1980-7791.

LOPERENA ROTA, Demetrio. Los principios del derecho ambiental. Madrid: Editorial Civitas, 1998.

LOZANO CUTANDA, Blanca; TURRILLAS, Juan-Cruz Alli. Administración y legislación ambiental. 7. ed. Madrid: Dykinson, 2013.

MARCHESAN, Ana Maria Moreira; STEIGLEDER, Annelise Monteiro (Orgs.). Crimes ambientais: Comentários a Lei 9.605/98. Porto Alegre: Livraria do advogado, 2013.

MILARÉ, Édis. Direito do ambiente: a gestão ambiental em foco. 7. ed. São Paulo: Revista dos Tribunais, 2011.

MIR PUIG, Santiago. Derecho penal: parte general. 7. ed. Barcelona: Editorial Reppertor, 2005.

MIR PUIG, Santiago. Direito Penal: Fundamentos e teoria do delito. Tradução de Cláudia Viana Garcia e José Carlos Nobre Porciúncula Neto. São Paulo: Revista dos Tribunais, 2007.

MOLINA, Antonio García-Pablos; GOMES, Luiz Flávio. Direito Penal: Fundamentos e limites do Direito Penal. 3. ed. São Paulo: Revista dos Tribunais, 2012.

MUÑOZ CONDE, Francisco; GARCÍA ARÁN, Mercedes. Derecho penal: parte general. 9. ed. Valência: Tirant lo blanch, 2015. PÉREZ LUÑO, Antonio Henrique. Perspectivas e tendências atuais do Estado Constitucional. Tradução de Jose Luis Bolzan de Morais e Valeria Ribas do Nascimento. Porto Alegre: Livraria do advogado editora, 2012.

PASOLD, Cesar Luiz. Metodologia da pesquisa jurídica: teoria e prática. 12. ed. São Paulo: Conceito Editorial, 2011. 
VIVIANI, Rodrigo Andrade. O direito penal como instrumento destinado à proteção do meio ambiente: análise no contexto da constituição federal brasileira. Revista Eletrônica Direito e Política, Programa de Pós-Graduação Stricto Sensu em Ciência Jurídica da UNIVALI, Itajaí, v.11, n.2, 2o quadrimestre de 2016. Disponível em: www.univali.br/direitoepolitica - ISSN 1980-7791.

ROXIN, Claus. A proteção de bens jurídicos como função do

Direito Penal. Tradução de André Luís Callegari. 2. ed. Porto Alegre: Livraria do advogado, 2009.

SILVA SÁNCHEZ, Jesús-Maria. La expansión del Derecho Penal: Aspectos de la política criminal en las sociedades postindustriales. 2. ed. Madrid: Civitas, 2001.

SILVA SÁNCHEZ, Jesús-María. Aproximação ao Direito Penal contemporâneo. Tradução de Roberto Barbosa Alves. São Paulo: Revista dos Tribunais, 2011.

SARLET, Ingo Wolfgang; FENSTERSEIFER, Tiago. Direito ambiental: Introdução, fundamentos e teoria geral. São Paulo: Saraiva, 2014.

SILVA, José Afonso. Direito ambiental constitucional. 4. ed. São Paulo: Malheiros, 2003.

SANTOS, Juarez Cirino. Direito penal: parte geral. 3. ed. São Paulo: Curitiba: Lumen Juris, 2008.

SCHÜNEMANN, Bernd. Temas actuales y permanentes del Derecho penal después del milenio. Madrid: Tecnos, 2002.

SIRVINSKAS, Luís Paulo. Manual de direito ambiental. 9. ed. São Paulo: Saraiva, 2011.

WELZEL, Hans. Direito penal. Tradução de Afonso Celso Rezende. 4. ed. Campinas: Editora Romana, 2004.

Submetido em: Fevereiro de 2016.

Aprovado em: Junho de 2016. 